\title{
Analisis Faktor-Faktor yang Memengaruhi Output Sektor Industri Pengolahan di Provinsi Jawa Tengah
}

\author{
Analysis Effect of Macroeconomic Variables on Manufacturing \\ Industrial Output in Central Java Province
}

\section{Selviana Raharjo ${ }^{1}$, Dedi Budiman Hakim² and Sahara ${ }^{2}$}

Diterima: 31 Agustus 2020

Disetujui: 5 Januari 2021

\begin{abstract}
Abstrak: Sektor industri pengolahan memiliki kontribusi terbesar dalam perekonomian Jawa Tengah. Meskipun demikian, kinerja sektor industri pengolahan menunjukkan perlambatan pertumbuhan dalam beberapa tahun terakhir. Terdapat beberapa faktor yang memengaruhi kinerja output sektor industri pengolahan. Penelitian ini bertujuan untuk mengetahui faktorfaktor yang memengaruhi output sektor industri pengolahan di Provinsi Jawa Tengah dan mengidentifikasi variabel mana yang memiliki komposisi tersbesar dalam menjelaskan output sektro industri pengolahan. Variabel-variabel yang digunakan dalam penelitian ini diantaranya adalah ekspor, impor, investasi PMA, invetsasi PMDN, tenaga kerja, PDRB sektor industry pengolahan, infrastruktur jalan dan listrik, industri, UMP, variabel inflasi dan dummy otonomi daerah. Metode yang digunakan dalam penelitian ini adalah Vector Error Correction Model (VECM). Hasil analisis menunjukkan bahwa dalam jangka panjang investasi PMDN dan invetsasi PMA berpengaruh signifikan terhadap output sektor industri pengolahan Jawa Tengah. Di sisi lain analisis FEVD menunjukkan bahwa secara berurutan variabel ekspor, pertumbuhan output sektor industri, investasi PMA, kegiatan impor, tenaga kerja, inflasi, UMP dan investasi PMDN secara berurutan memiliki komposisis terbesar dalam menjelaskan fluktuasi output sektor industri pengolahan Jawa Tengah.
\end{abstract}

Kata Kunci: FEVD, Jawa Tengah, output sektor indusri pengolahan, VECM

\begin{abstract}
Industrial manufacturing sektor has the biggest contribution to regional economic development of Central Java Province but in the last few years the output of industrial sector experienced a slowing down growth. This industrial manufacturing sector is influenced by many variables. This study identified the effect of macroeconomic variables on industrial manufacturing sector performance in Central Java Province. Macroeconomic variables used in this study were export, import, domestic investment, foreign direct investment, province minimum wage, labour, road and electricity infrastructure, inflation and dummy regional outonom. The methods used to analyze this study were vector error correction model (VECM). A forecast error variance decomposotion (FEVD) test also were used to show the contributions of each macroeconomic variables to the output of manufacture sector. The result of VECM equation shows that in the long-term both domestic investment (PMDN) and foreign investment (PMA) significantly influenced industrial manufacture output. Meanwhile FEVD test shows export, output growth, foreign investment and labour has the bigest composition on explaining manufacturing fluctuations in long-term.
\end{abstract}

Keywords: FEVD, Central Java, industrial manufacturing output, VECM

\footnotetext{
${ }^{1}$ Program Studi Ilmu Perencanaan Pembangunan Wilayah dan Perdesaan, Institut Pertanian Bogor

${ }^{2}$ Departemen Ilmu Ekonomi, Institut Pertanian Bogor
}

Korespondensi: selvimydocument@gmail.com 


\section{PENDAHULUAN}

Keseriusan pemerintah dalam membangun industri nasional diamanatkan dalam UU No. 3 Tahun 2014 tentang Perindustrian. Pemerintah meletakkan industri sebagai salah satu pilar terpenting dalam pembangunan. Industrialisasi merupakan salah satu strategi yang dilakukan oleh daerah untuk mampu menciptakan pertumbuhan ekonomi yang cepat karena kemampuannya dalam menciptakan nilai tambah tinggi, meningkatkan output, memacu pertumbuhan sektor perekonomian lain, memiliki keterkaitan antar sektor (hulu dan hilir) serta menciptakan multiplier effect. Dalam Rencana Induk Pembangunan Industri Nasional (RIPIN) 2015-2035, Provinsi Jawa Tengah termasuk kedalam Wilayah Pengembangan Industri (WPI) yang diharapkan mampu menciptakan industri tangguh yang dapat memberikan kontribusi terhadap pertumbuhan perekonomian regional dan nasional, sesuai dengan visi pembangunan industri nasional itu sendiri yaitu "Indonesia Menjadi Negara Industri Tangguh pada Tahun 2035".

Pemerintah daerah Provinsi Jawa Tengah merespon dengan cepat keseriusan pemerintah pusat dalam upaya membangun industri tangguh dengan mengesahkan Peraturan Daerah No. 10 Tahun 2017 tentang Rencana Pembangunan Industri Provinsi (RPIP) 2017-2037. Dalam pembangunannya, pemerintah saat ini berekspektasi lebih terhadap sektor industri pengolahan untuk bisa lebih meningkatkan pertumbuhan ekonomi Jawa Tengah. Sektor industri pengolahan menjadi sektor unggulan Provinsi Jawa Tengah yang menjadi salah satu fokus dan dapat diandalkan berperan dalam membantu mencapai tujuan prioritas pembangunan yang terdapat dalam Rencana Pembangunan Jangka Menengah Daerah Provinsi Jawa Tengah (RPJMD) yaitu penanggulangan kemiskinan, pengangguran, peningkatan kapasitas dan daya saing ekonomi serta peningkatan kesempatan kerja.

Di level regional, sektor industri pengolahan memiliki kontribusi terbesar terhadap pembentukan PDRB Jawa Tengah (34.88\%) disusul dengan sektor perdagangan besar dan eceran (14.27 \%) serta sektor pertanian (13.69 \%) (BPS 2017). Kontribusi terhadap penyerapan tenaga kerja, sektor industri merupakan sektor penyerap tenaga kerja terbesar ketiga (3.25 juta orang) setelah sektor pertanian (5.1 juta orang) dan sektor perdagangan (3.7 juta orang) (BPS 2017). Pengaruhnya terhadap aktivitas ekspor, Provinsi Jawa Tengah didominasi oleh ekspor sektor industri pengolahan dengan pangsa pasar sebesar $90 \%$ dari total ekspor yang dilakukan. Investasi PMA dan investasi PMDN sektor industri pengolahan memiliki proporsi penyerapan investasi terbesar dibandingkan sektor perekonomian lain terhadap total investasi di Jawa Tengah (BKPM 2018).

Kinerja industri pengolahan masih menjadi suatu hal penting yang harus terus diperbaiki di level regional, guna menjamin keberlangsungan industri dalam perannya menopang output Jawa Tengah. Sektor industri pengolahan Jawa Tengah menunjukkan trend penurunan pertumbuhan pada beberapa tahun terakhir (BPS 2018). Penurunan kinerja tersebut menjadi suatu hal yang serius mengingat peranan dan kontribusinya terhadap perekonomian Jawa Tengah yang besar. Kustanto (2012) menyatakan bahwa ketika PDB total semakin tinggi sedangkan kontribusi dari sektor industri pengolahan menurun maka menunjukkan gejala-gejala deindustrialisasi atau penurunan kinerja sektor industri pengolahan. Jika kondisi tersebut berlanjut tentunya dapat berdampak pada perolehan output total Jawa Tengah dimana pada Tahun 2020 target pertumbuhan ekonomi Provinsi Jawa Tengah mencapai 7\% sehingga peran sektor industri pengolahan sebagai penyumbang kontribusi PDRB terbesar dibutuhkan (jatengprov.go.id).

Kondisi industri pengolahan tidak dapat terlepas dari beberapa faktor perekonomian yang menopangnya baik secara langsung dan tidak langsung (Bapennas 2010). Terdapat beberapa faktor yang dapat memengaruhi output sektor industri berdasarkan Insitute for Management Development (IMD). Pertama, kinerja perdagangan, 
investasi, ketenagakerjaan dan stabilitas harga. Kedua, inefisiensi kelembagaan pemerintahan dan pengelolaan keuangan negara/fiskal. Ketiga, banyaknya peraturan perundang-undangan yang kurang kondusif bagi dunia usaha. Keempat, rendahnya produktivitas dunia usaha. Kelima, terbatasnya infrastruktur, baik infrastruktur fisik, teknologi dan infrastruktur lainnya yang menunjang. Dalam upaya mendorong pertumbuhan kinerja sektor industri, maka tentunya peran dan dukungan pemerintah diperlukan melalui berbagai kebijakannya dan intervensi-intervensi yang dilakukan

Karakteristik sektor industri pengolahan daerah menunjukkan bahwa faktor-faktor perekonomian seperti modal, tenaga kerja, investasi serta keadaan infrastruktur masih menjadi faktor dominan penunjang pertumbuhan sektor industri (Eng Der Van 2009; Prasetyo 2010; Novitasari 2017; UNIDO 2019). Memahami bagaimana variabel makroekonomi berpengaruh terhadap output sektor industri pengolahan dapat memberikan gambaran bagi para stakeholder dalam menentukan arah kebijakan yang dibuat. Dengan demikian tujuan dari penelitian ini adalah untuk mengetahui faktor-faktor yang memengaruhi output sektor industri pengolahan Jawa Tengah dan mengatahui faktor-faktor yang memiliki kontribusi terbesar memengaruhi output sektor industri pengolahan dalam jangka panjang.

\section{METODE}

Penelitian ini menggunakan data sekunder, berupa data time series periode Tahun 1988 sampai dengan periode 2018. Data tersebut diperoleh dari lembaga statistik BPS Provinsi Jawa Tengah, BPS pusat dan BKPM Jawa Tengah. Pengolahan data dilakukan dengan menggunakan perangkat lunak Eviews 9. Data sekunder yang digunakan dalam penelitian ini adalah pertumbuhan PDRB sektor industri pengolahan atas dasar harga konstan 2010, upah minimum provinsi (UMP), investasi PMA riil, investasi PMDN riil, ekspor riil, impor riil, tenaga kerja, infrastruktur panjang jalan dan listrik, inflasi serta dummy otonomi daerah.

Pendekatan ekonometrika Vector Error correction Model (VECM) digunakan dalam menjawab tujuan pertama. Pendekatan metode VECM ini digunakan karena keberadaan data yang tidak stasioner pada level namun terkointegrasi serta antar variabel memiliki korelasi (saling memengaruhi). Variabel target (dependen) sebagai pendekatan untuk melihat kinerja sektor indutri pengolahan yang digunakan dalam penelitian ini adalah variabel pertumbuhan PDRB sektor industri pengolahan atas dasar harga konstan 2010. Sementara variabel bebas (independen) dalam penelitian ini adalah variabel ekspor di sektor industri pengolahan, impor bahan baku dan barang modal, invetsasi PMA dan PMDN sektor industri, jumlah tenaga kerja sektor industri, infrastruktur panjang jalan, variabel upah minimum provinsi (UMP), inflasi serta variabel dummy otonomi daerah dimasukan dalam persamaan. Variabel dummy digunakan dalam persamaan dan dimasukan sebagai variabel exogenous, dimana 0: tidak ada kebijakan otonomi daerah; 1 : ada kebijakan otonomi daerah. Variabel infrastruktur jalan dan listrik dimasukkan sebagai variabel eksogen.

Pemilihan model didasarkan pada beberapa penelitian yaitu Andrei (2015) dan Szkorupova (2014). Sedangkan pemilihan variabel didasarkan pada beberapa penelitian terdahulu yaitu Novitasari (2015), Kilavuz (2012) dan Aftab (2016). Model persamaan VECM umum adalah:

$$
\Delta y_{t}=\mu_{o x}+\mu_{1 x} t+\Pi_{x} y_{t-1}+\sum_{i=1}^{k-1} \Gamma_{i x} \Delta y_{t-1}+\varepsilon_{t}, t=1,2, \ldots
$$


Estimasi model VECM dengan variabel dummy:

$\Delta y_{t}=\mu_{o x}+\mu_{1 x} t+\sum_{i=1}^{k-1} \Gamma_{i x} \Delta y_{t-1}+\Pi_{x} y_{t-1}+Z_{1} J L N+Z_{2}$ LIS $+Z_{3}$ Dummy $+\varepsilon_{t}$

Persamaan VECM memiliki informasi persamaan jangka pendek dan jangka panjang.

Notasi persamaan jangka panjang yaitu $\Pi_{x}$. Dimana $\Pi_{x \text { dibagi kedalam dua persamaan }}$ matriks yang berbeda yaitu matriks $\alpha$ dan matriks $\beta$. Matriks $\beta$ merupakan persamaan kointegrasi jangka panjang (ECT) dan $\alpha$ merupakan koefisien vector koreksi eror yang menunjukkan kecepatan penyesuaian jangka pendek menuju jangka panjang. Model persamaan kointegrasi jangka panjang (ECT):

$$
E C T_{t-1}=y_{t-1}-\beta_{0}+\beta_{1} X_{t-1}
$$

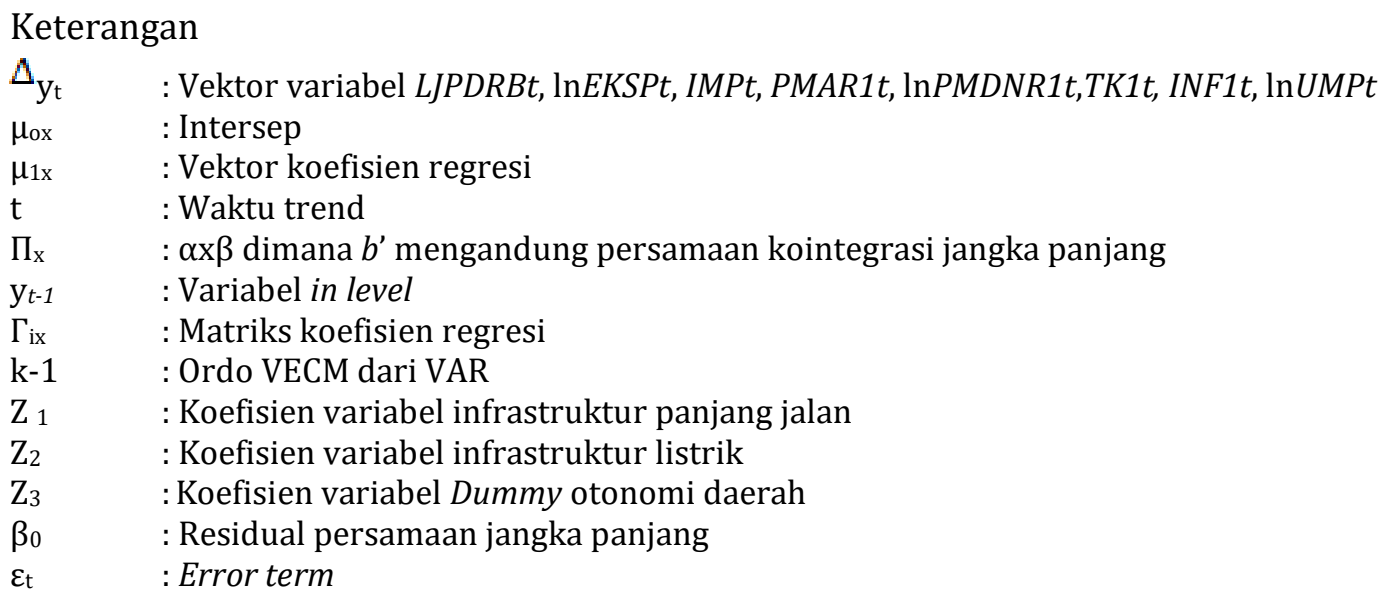

Dalam menjawab tujuan kedua, menggunakan analisis Impulse Response Function (IRF) serta Forecast Error Variance Decomposition (FEVD). Analisis IRF digunakan untuk mengetahui respon suatu variabel dari sebuah guncangan (shock) terhadap variabel dirinya sendiri atau variabel endogen lainnya. Selain itu analisis ini digunakan untuk mengetahui bagaimana perilaku setiap variabel tersebut untuk beberapa tahun kedepan. Dengan kata lain IRF mengukur pengaruh suatu shock pada suatu waktu terhadap variabel endogen pada waktu tersebut dan dimasa yang akan datang.

Analisis FEVD digunakan untuk memprediksi kontribusi presentasi varian setiap peubah karena adanya peubah-peubah tertentu dalam sistem VAR. Dalam analisis IRF sebelumnya digunakan untuk melihat guncangan dari suatu peubah terhadap peubah lainnya, dalam analisis Variance Decomposition ini digunakan untuk menggambarkan relatif pentingnya setiap peubah dalam sistem VAR karena adanya guncangan (Juanda 2012).

\section{HASIL DAN PEMBAHASAN}

Analisis Faktor-faktor yang memengaruhi output sektor industri pengolahan dilakukan dengan pendekatan ekonometrika Vector Error Correction Model (VECM). Sebelum mengestimasi model, maka terlebih dahulu dilakukan uji pra-estimasi pada data variabel-variabel yang akan diestimasi dalam model. Tahap pertama adalah melakukan uji akar unit (unit root test). Uji akar unit dilakukan dengan menggunakan metode Augmenthed Dickey Fuller (ADF). Kriteria dari uji ADF adalah dengan membandingkan 
antara nilai t-statistik ADF dengan nilai Mckinnon Critical Values. Jika nilai t-statistik ADF > Mckinnon Critical Values maka data tersebut tidak stasioner pada level dan mengandung akar unit. Jika data yang digunakan bersifat tidak stasioner maka dilanjutkan untuk mengetahui pada derajat berapa data tersebut dapat stasioner. Hasil pengujian akar unit menunjukan bahwa variabel LN_LIST, dummy Otonomi daerah, LN_EKSP, LN_JAL, TK1 dan LN_UMP1 tidak stasioner pada level dan stasioner pada first difference, sedangkan variabel PMAR1, LN_PMDNR1, LJPDRB dan INF1 stasioner pada level dengan taraf nyata lima persen. Terdapatnya variabel-variabel yang tidak stasioner dalam persamaan mengidentifikasikan adanya hubungan jangka panjang antar variabel tersebut.

Uji stabilitas VAR penting dilakukan untuk mengetahui model VAR stabil atau tidak, karena berpengaruh terhadap valid tidaknya uji Impulse Response Function (IRF) dan uji Forecast Error Variance Decomposition (FEVD) yang dilakukan. Jika semua nilai absolutnya bernilai $<1$ maka model VAR tersebut dianggap stabil sehingga uji Impuls Response Function (IRF) dan uji Forecast Error Variance Decomposition (FEVD) yang dilakukan dianggap valid (Firdaus 2011). Hasil dari uji stabilitas VAR menunjukkan bahwa sistem VAR stabil pada lag 1 dengan nilai modulus berkisar antara 0.111145- 0.994010 atau lebih kecil dari satu dimana semua variabel berada di dalam unit circle.

Penentuan lag optimal penting dalam sistem VAR karena pada tahap uji kointegrasi sangat peka terhadap panjang lag. Lag optimal diperlukan untuk menangkap lama pengaruh dari setiap peubah terhadap perubah lainnya (Juanda 2012).

Tabel 1. Hasil Uji Kointegrasi

\begin{tabular}{cclllll}
\hline No & Hipotesis Nol & $\begin{array}{l}\text { Hipotesis } \\
\text { Alternatif }\end{array}$ & $\begin{array}{l}\text { Eigen } \\
\text { Value }\end{array}$ & Trace Statistic & $\begin{array}{c}\text { Nilai } \\
\text { Kritis } \\
\text { (5\%) }\end{array}$ & Prob.** \\
\hline 1 & $\mathrm{r}=0$ & $\mathrm{r} \leq 1$ & 0.997268 & $474.4231^{* *}$ & 159.5297 & 0.0000 \\
2 & $\mathrm{r}=1$ & $\mathrm{r} \leq 2$ & 0.981459 & $303.2476^{* *}$ & 125.6154 & 0.0000 \\
3 & $\mathrm{r}=2$ & $\mathrm{r} \leq 3$ & 0.938411 & $187.6018^{* *}$ & 95.75366 & 0.0000 \\
4 & $\mathrm{r}=3$ & $\mathrm{r} \leq 4$ & 0.772093 & $106.7711^{* *}$ & 69.81889 & 0.0000 \\
5 & $\mathrm{r}=4$ & $\mathrm{r} \leq 5$ & 0.698877 & $63.88536^{* *}$ & 47.85613 & 0.0008 \\
6 & $\mathrm{r}=5$ & $\mathrm{r} \leq 6$ & 0.459964 & 29.07855 & 29.79707 & 0.0603 \\
7 & $\mathrm{r}=6$ & $\mathrm{r} \leq 7$ & 0.318642 & 11.21107 & 15.49471 & 0.1989 \\
8 & $\mathrm{r}=7$ & $\mathrm{r} \leq 8$ & 0.002917 & 0.084726 & 3.841466 & 0.7710 \\
\hline
\end{tabular}

**Uji Trace mengindikasikan terdapat 5 persamaan kointegrasi pada level $5 \%$

Sumber: Diolah, 2020

Penentuan lag optimal ditentukan berdasarkan informasi yang didapat dari beberapa kriteria yang digunakan dalam sistem VAR, yaitu Likelihood Ratio (LR), Akaike Information Criteria (AIC), Schwarz Information Criteria (SC), Final Prediction Error (FPE) dan Hannan-Quinn Criteria (HQ). Pada penelitian ini semua kriteria mengacu pada lag pertama sebagai lag optimal. Kointegrasi dalam sebuah persamaan menunjukan adanya hubungan keseimbangan dalam jangka panjang.

Uji kointegrasi dilakukan dengan menggunakan pendekatam Johanson Cointegration dimana nilai trace statistic dibandingkan dengan nilai critical value pada taraf 5 persen. Jika nilai trace statistic > critical value (5\%) maka sistem persamaan tersebut terkointegrasi. Pada Tabel 2 hasil uji trace statistic menunjukan terdapat 5 persamaan kointegrasi pada tarap 5 persen. Hasil tersebut menunjukan terdapat hubungan jangka panjang antara variabel-variabel yang diduga memengaruhi sektor industri pengolahan terhadap pertumbuhan PDRB sektor industri pengolahan. Dengan demikian model yang digunakan adalah model VECM.

Pendekatan ekonometrika vector error correction model (VECM) digunakan karena keberadaan data yang tidak stasioner pada level namun terkointegrasi. VECM 
menghasilkan informasi keseimbangan jangka panjang antar variabel endogen dalam sistem persamaan serta mengukur kecepatan (error correction) variabel- variabel dalam mengkoreksi persamaan menuju keseimbangan jangka panjangnya. Hasil analisis VECM disajikan pada Tabel 3 .

Tabel 2. Hasil Estimasi VECM

\begin{tabular}{llll}
\hline \multicolumn{2}{c}{ Persamaan Jangka Pendek } & \multicolumn{2}{c}{ Persamaan Jangka Panjang } \\
\hline \multicolumn{1}{c}{ Variabel } & \multicolumn{1}{c}{ Koefisien } & \multicolumn{1}{c}{ Variabel } & Koefisien \\
\hline CointEq1 & $-0.815349^{* *}$ & LJPDRB1(-1) & 1.000000 \\
D(LJPDRB(-1) & 0.178199 & INF(-1) & 0.000000 \\
D(INF1(-1) & 0.092394 & PMAR1(-1) & 0.000000 \\
D(PMAR1(-1) & $-3.32 E-12^{* *}$ & LN_EKSP(-1) & 0.000000 \\
D(LN_EKSP(-1) & $18.05643^{* *}$ & IMP(-1) & 0.000000 \\
D(IMP(-1) & $-1.55 E-08$ & LN_UMP1(-1) & -3.667943 \\
D(LN_UMP1(-1) & -1.451282 & LN_PMDNR1(-1) & $-5.508610^{* *}$ \\
D(LN_PMDNR1(-1) & -0.334569 & PMAR1 (-1) & $3.25 E-11^{* *}$ \\
D(TK1(-1) & $-6.34 \mathrm{E}-06^{* *}$ & C & 165.7930 \\
DUMMY1 & $4.932189^{* *}$ & & \\
LN_JAL & 0.162602 & & \\
LN_LIST & -1.373207 & & \\
C & 25.27540 & & \\
\hline
\end{tabular}

**Signifikan pada taraf nyata $5 \%$

Sumber: Diolah, 2020

Estimasi VECM pada Tabel 2 memperlihatkan pengaruh variabel dalam jangka pendek dan jangka panjang. Berdasarkan analisis tersebut, dalam persamaan jangka pendek terdapat empat variabel yang signifikan berpengaruh terhadap PDRB sektor industri pengolahan pada taraf nyata lima persen, yaitu variabel tenaga kerja (TK1), variabel ekspor (LN_EKSP), variabel investasi PMA (PMAR1) dan variabel dummy otonomi daerah (DUMMY1). Sedangkan variabel jalan (LN_JAL), listrik (LN_LIST), investasi PMDN (LN_PMDNR1) dan variabel impor (IMP) serta variabel pertumbuhan PDRB sektor industri (LJPDRB) pada satu periode sebelumnya, tidak berpengaruh signifikan. Persamaan tersebut menjelaskan bahwa pertumbuhan PDRB sektor industri pengolahan saat ini, dipengaruhi secara signifikan oleh variabel ekspor, jumlah tenaga kerja, investasi PMA periode sebelumnya dan variabel dummy otonomi daerah.

Hasil estimasi VECM juga memperlihatkan bahwa terdapat hubungan jangka panjang pada variabel makroekonomi dalam model terhadap pertumbuhan output sektor industri pengolahan Jawa Tengah. Estimasi model VECM persamaan jangka panjang menunjukan terdapat dua variabel yang berpengaruh signifikan terhadap pertumbuhan PDRB sektor industri pengolahan, yaitu investasi PMDN (LN_PMDNR1) dan investasi PMA (PMAR1). Kenaikan investasi PMDN pada periode sebelumnya berpengaruh positif dan signifikan terhadap variabel output sektor industri pengolahan. Berbeda dengan investasi PMDN, investasi PMA periode sebelumnya berpengaruh negatif dan signifikan terhadap pertumbuhan PDRB sektor industri pengolahan Jawa Tengah. Hasil estimasi model VECM menghasilkan nilai kointegrasi (CointEq1) negatif dan signifikan (prob < 0.05) dengan koefisien bernilai -0.815349. Nilai kointegrasi yang bernilai negatif dan signifikan mengindikasikan terdapatnya mekanisme penyesuaian dari jangka pendek menuju jangka panjang (Firdaus 2011; Juanda 2012). Nilai tersebut menunjukan bahwa kesalahan dikoreksi sebesar 81.5 persen menuju keseimbangan jangka panjang. Persamaan VECM dengan variabel pertumbuhan PDRB sebagai variabel target; 


$$
\begin{aligned}
\triangle L J P D R B_{t}=- & 0.815 E C T_{t-1}+0.178 \Delta J P D R B_{t-1}+0.0 .092 \Delta I N F 1_{t-1} \\
& -3.32 E-12 \Delta P M A R 1_{t-1}+18.056 \Delta \ln E K S P_{t-1}-1.55 E-08 \Delta I M P_{t-1} \\
& -1.451 \Delta \ln U M P 1_{t-1}-0.335 \Delta \ln P M D N R 1_{t-1}-6.34 E-06 \Delta T K 1_{t-1} \\
& +0.163 \ln J A L-0.137 \ln L I S T+4.932 D U M M Y 1+25.275
\end{aligned}
$$

Model persamaan jangka panjang (ECT):

$$
\begin{gathered}
E C T_{t-1}=1.000 \text { LJPDRB }_{t-1}+5.51 P M D N R 1_{t-1}-3.25 E-11 P M A R 1_{t-1} \\
+3.668 \ln U M P 1_{t-1}+165.793
\end{gathered}
$$

Hasil pengolahan menunjukan bahwa investasi PMDN mampu meningkatkan pertumbuhan PDRB sektor industri pengolahan dibandingkan dengan investasi PMA dalam jangka panjang Hasil tersebut didukung penelitian Hapsari (2016) menyatakan bahwa investasi PMA tidak mampu meningkatkan pertumbuhan ekonomi regional sebaliknya investasi PMDN mampu meningkatakan pertumbuhan ekonomi. Berbeda dengan penelitian Latip (2009) menyatakan bahwa investasi PMA mampu meningkatkan perekonomian provinsi-provinsi di Indonesia.

Ostry et al. (2010) menyatakan bahwa investasi PMA kemungkinan besar dapat meningkatkan output dalam jangka pendek dan membatasi peningkatan output dalam jangka panjang, hal tersebut disebabkan karena investasi asing yang diterima merupakan aksi dari para investor untuk melindungi nilai investasinya sehingga bersifat sementara. Selain itu invetasi asing sangat rentan terhadap suku bunga dan faktor eksternal sehingga dapat terjadi penurunan produktivitas modal dalam jangka panjang (diminishing marginal productivity of capital). Hapsari (2016) menyatakan bahwa investai PMA dalam lingkup skala yang lebih kecil (provinsi) belum tentu dapat meningkatkan perekonomian, sehingga investasi PMDN harus lebih ditingkatkan namun tentunya tidak melupakan investasi PMA yang juga sama-sama memiliki prospek dalam meningkatkan pertumbuhan industri pengolahan jika dilakukan dengan memperhatikan keadaan perekonomian wilayah yang lebih baik sehingga mampu menyerap investasi PMA dengan optimal.

Investasi PMDN dan investasi PMA pada dasarnya sama-sama memiliki potensi dalam meningkatkan perekonomian jika dilakukan efektif dan tepat sasaran (Hapsari 2016). Latip (2009) dalam penelitiannya menyatakan bahwa kesuksesan investasi PMA dalam menstimulasi pertumbuhan tergantung pada keadaan dan kemampuan perekonomian di daerah itu sendiri dalam menyerap investasi asing, seperti sumberdaya yang handal, kebijakan investasi, kestabilan makroekonomi, pangsa pasar yang luas, keamanan yang stabil, serta infrastruktur yang memadai. Ketersediaan fasilitas prasarana industri seperti pergudangan, jalur transportasi untuk logistik barang dan lain-lain. Selain itu kekurangan teknologi juga dapat membuat investasi yang dilakukan menjadi tidak efisien (Palupy 2019).

Variabel ekspor sektor industri (LN_EKSP) berpengaruh positif dan signifikan terhadap output sektor industri pengolahan. Dijelaskan bahwa dalam jangka pendek kenaikan ekspor sebesar satu persen pada tahun sebelumnya akan meningkatkan output sektor industri pengolahan sebesar 18.05 persen. Hal tersebut mengimplikasikan bahwa kegiatan ekspor memegang peranan penting dalam peningkatan pertumbuhan output sektor industri pengolahan Jawa Tengah. Kegiatan ekspor dapat memperluas pasar sehingga dapat mendorong terjadinya peningkatan output sektor industri pengolahan. Hal ini didukung dengan hasil penelitian Alam (2014); Kilavuz (2012); Sitorus (2008); dimana kegiatan ekspor dapat berperan sebagai motor penggerak pertumbuhan ekonomi.

Berbeda dengan variabel ekspor, kenaikan impor (IMP1) sebesar satu persen pada tahun sebelumnya menurunkan output sektor industri pengolahan sebesar 7.54E-12 persen namun tidak signifikan dalam jangka pendek. Hasil penelitian ini sesuai dengan 
Novitasari (2015) dan Kilavuz (2012) yang menyatakan kegiatan impor yang terjadi disektor industri pengolahan belum mampu mendorong technological process yang diharapkan. Produktivitas dan efisiensi yang diharapkan dari kegiatan impor belum dapat bisa diandalkan sesuai harapan. Kegiatan impor yang dilakukan memiliki nilai lebih besar setiap tahunnya dibandingkan nilai ekspornya sehingga membebani neraca perekonomian (Jhingan 2008). Dalam Kilavuz (2012) menjelaskan bahwa berpengaruh negatifnya impor terhadap pertumbuhan sektor industri dapat disebakan kerana faktor ketidak mampuan negara-negara berkembang mencapai pertumbuhan pada level tertentu, salah satunya kegiatan ekspor yang dilakukan tidak mencapai tingkat yang diharapkan.

Disisi lain, Imbruno (2018) dan Feng L (2012) meyatakan bahwa kegiatan impor bahanbaku intermediet dapat meningkatkan efisiensi produksi karena terdapatnya transfer technology yang didapat dari negara-negara produsen sehingga dapat meningkatkan kinerja sektor manufaktur. Selain itu kegiatan impor dapat meningkatkan skala dan partisipasi dalam pasar ekspor. Hal tersebut menunjukan tidak terjadinya technological process yang sebelumnya diharapkan dapat terjadi. Todaro (2006) menyatakan kegiatan impor memungkinkan dalam menyerap teknologi secara lebih efektif yang menjadi pondasi dari kekayaan negara maju. Dengan demikian kegiatan impor harus dilakukan secara efisien dan kegiatan ekspor harus senantiasa dikembangkan agar produk lebih memiliki daya saing di pasaran.

Variabel tenaga kerja (TK1) berpengaruh negatif dan signifikan terhadap output sektor industri pengolahan dalam jangka pendek. Hal ini dapat dejelaskan bahwa kenaikan jumlah tenaga kerja sektor industri pengolahan sebesar satu persen pada periode sebelumnya menurunkan output sektor industri pengolahan sebesar 6.34E-06 persen. Hal tersebut mengindikasikan bahwa produktivitas dari tenaga kerja sektor industri pengolahan masih rendah dan menunjukan bahwa manfaat dari tenaga kerja belum dapat dirasakan dalam jangka pendek serta memerlukan lag/waktu untuk kemudian bisa memberikan manfaat terhadap output Jawa Tengah. Produktivitas tenaga kerja yang rendah disebabkan karena industri pengolahan yang berbasis sumberdaya (resource-based manufacturing) serta bersifat padat karya dimana sebagian besar tenaga kerja memiliki keterampilan rendah dan kebutuhan modal rendah. Selain itu, kendala ketidak sesuaian keterampilan kerja (miss-matched) serta karakteristik dari daerah (budaya dan etik kerja) masih menjadi kendala yang memengaruhi produktivitas tenaga kerja dalam pembangunan industri pengolahan di provinsi-provinsi di Indonesia (Badriah 2019).

Sejak tahun 2000-an rata-rata upah sektor industri nasional meningkat dengan sangat cepat dibandingkan dengan produktivitas tenaga kerja yang tumbuh dengan tidak signifikan (lambat) (Aswicahyono 2018). Meskipun demikian, tenaga kerja merupakan faktor penting dalam pembangunan ekonomi dan dalam membantu meningkatkan kinerja sektor industri pengolahan khususnya. Hal tersebut mengindikasikan bahwa pemerintah harus fokus memperbaiki kualitas dari sumberdaya manusia. Tidak hanya investasi fisik, tetapi investasi modal manusia harus ditingkatkan melalui peningkatan keterampilan, pendidikan serta penelitian dan pengembangan (Anwar 2008; Rukumnuaykit 2015; Aftab 2016).

Variabel dummy otonomi daerah menunjukkan nilai positif dan signifikan terhadap output sektor industri pengolahan dengan koefisien sebesar 4.932189. Dimana dengan diterapkannya sistem otonomi daerah berdampak positif pada peningkatan output sektor industri pengolahan. Sistem otonomi daerah akan menguntungkan bagi daerah yang memiliki kekayaan sumberdaya serta daerah yang merupakan pusat perdagangan srategis dan tentunya dikelola dengan efektif dan efisien (Pratiwi et al. 2001). Berubahnya sistem pemerintahan yang awalnya tresentralisasi kemudian menjadi terdesentralisasi memudahkan pemerintah dalam proses perencanaan dan pembangunan yang lebih matang dan terfokus diberbagai sektor khususnya di sektor industri pengolahan. 
Pemerintah dengan mandiri memiliki kewenangan untuk mengelola perekonomiannya, ditambah dengan pengetahuan yang lebih baik mengetahui keadaan daerahnya sehingga sumberdaya lokal dapat termanfaatkan dengan optimal.

Pembangunan dan pengembangan Sektor industri pengolahan memerlukan berbagai intervensi melalui peran campur tangan pemerintah di dalamnya. Peranannya dalam menarik investasi, penyediaan barang publik (infrastruktur), akses pasar yang luas, kemudahan birokrasi dan berbagai insentif serta kebijkan lainnya seperti penetapan upah minimum. Berpengaruhnya sistem pemerintahan otonomi daerah mengimplikasikan peningkatan peran pemerintah daerah terhadap perekonomian, terutama dalam membuat berbagai inovasi kebijakan-kebijakan khususnya terkait sektor industri pengolahan. Penerapan otonomi daerah tentunya berbeda-beda di setiap derahnya. Pembangunan sektor industri memerlukan keadaan ekonomi daerah yang stabil dan dapat menciptakan keadaan berusaha yang baik di daerahnya serta membutuhkan peranan sektor perekonomian lain karena pengembangan dan pembangunan sektor industri tidak terlepas dari keterkaitan sektor perekonomian lain (Rustiadi et al. 2011).

Nilai R-squared atau koefisien determinasi hasil uji menunjukkan bahwa variabel independen dalam model dapat menjelaskan variabel dependennya sebesar 96 persen. Sisanya dipengaruhi oleh variabel lain yang tidak dimasukkan pada model. Nilai probabilitas $F$ statistik memiliki nilai lebih kecil dari taraf nyata 5 persen yang memperlihatkan bahwa secara simultan variabel independen berpengaruh secara signifikan terhadap variabel dependennya.

Uji kausalitas Granger dalam penelitian ini digunakan untuk melihat urutan variabel yang paling banyak mempengaruhi variabel lainnya (ordering). Ordering diperlukan karena uji IRF dan uji FEVD bersifat sensitive terhadap urutan variabel. Uji kausalitas Granger dalam penelitian ini menunjukan bahwa urutan variabel yang paling memengaruhi variabel lainnya secara berurutan adalah variabel ekspor ( $L N \_E K S P$ ), impor $(I M P)$, pertumbuhan PDRB (LJPDRB), upah minimum provinsi (LN_UMP1), inflasi (INF1), jumlah tenaga kerja (TK1), investasi PMA (PMAR1) dan investasi PMDN (LN_PMDNR1).

Hasil analisis uji IRF pada Gambar 2 menunjukan bahwa guncangan yang terjadi pada variabel endogen memberikan respon dinamis pada variabel utamanya. Periode waktu yang digunakan untuk melihat dampak dari guncangan antar variabel adalah 10 periode (tahun). Hasil analisis menunjukan bahwa guncangan pada variabel ekspor direspon negatif oleh variabel output sektor industri pengolahan. Guncangan variabel ekspor tersebut langsung direspon negatif pada periode pertama oleh output sektor industri pengolahan sebesar 0.32 persen. Guncangan tersebut direspon negatif terbesar oleh output sektor industri pengolahan pada periode keempat sebesar 4.67 persen. Setelah itu pengaruh guncangan teresebut mulai menurun menuju titik keseimbangan sampai periode kesembilan sebesar 1.19 persen dan kembali memberikan respon yang tajam pada periode kesepuluh sebesar 4.00 persen. Hal tersebut menunjukkan bahwa respon dari variabel output sektor industri pengolahan akibat guncangan yang diberikan oleh variabel ekspor membutuhkan waktu yang cukup lama menuju titik keseimbangannya.

Guncangan sebesar satu standar deviasi pada variabel impor direspon positif oleh variabel output sektor industri pengolahan. Guncangan tersebut langsung direspon positif pada periode pertama sebesar 0.69 persen. Guncangan variabel impor tersebut direspon secara tajam oleh output sektor industri pengolahan pada periode kesepuluh sebesar 2.02 persen. Setelah itu pengaruh guncangan secara perlahan mulai menurun mendekati titik keseimbangannya (convergence) pada periode kesepuluh sebesar 0.25 persen. Hal tersebut menunjukkan respon suatu peubah akibat suatu guncangan semakin lama akan menghilang sehingga guncangan tersebut tidak memberikan dampak permanen terhadap output sektor industri pengolahan (Juanda 2012). Berpengaruh positifnya impor terhadap output sektor industri pengolahan mengindikasikan terjadinya transfer teknologi 
(technological process) dari kegiatan impor yang merupakan keuntungan kegiatan perdagangan yang dapat membuat proses produksi lebih efisien sehingga terjadi peningkatan output (Imbruno 2018).

Guncangan sebesar satu standar deviasi pada variabel tanaga kerja direspon positif oleh variabel output sektor industri pengolahan secara konsisten sampai pada periode kesepuluh. Pengaruh guncangan tersebut mulai direspon pada periode kedua sebesar 0.66 persen. Pengaruh guncangan mulai menurun menuju titik keseimbangannya sampai pada periode keempat sebesar 0.22 persen. Guncangan tersebut kembali direspon oleh variabel output sektor industri pengolahan secara tajam pada periode keenam sebesar 0.79 persen dan kembali menunjukkan penurunan pengaruh sampai pada periode kedelapan. Setelah itu pengaruh guncangan mulai menurun dan menuju titik keseimbangan (convergence) pada periode kesepuluh. Hal tersebut menunjukkan bahwa respon dari variabel output sektor industri terhadap guncangan variabel impor bersifat tidak permanen atau sementara.

Hasil uji IRF juga menunjukkan bahwa guncangan pada variabel output sektor industri pengolahan direspon positif oleh variabel dirinya sendiri dan cenderung berfluktuatif. Guncangan tersebut langsung direspon pada periode pertama sebesar 1.35 persen. Setelah melalui beberapa periode, guncangan variabel dirinya sendiri direspon negatif oleh output sektor industri pengolahan pada periode keenam sebesar 0.44 persen. Guncangan tersebut kemudian kembali memberikan respon yang positif terhadap output sektor industri pengolahan dan menuju pada titik keseimbangannya pada periode kesembilan sebesar 0.07 persen. Hal tersebut menunjukkan bahwa guncangan output sektor industri pengolahan tidak memberikan pengaruh permanen terhadap variabel dirinya sendiri dan membutuhkan waktu beberapa periode untuk menuju pada titik keseimbangannya (convergence).

Guncangan investasi PMA pada periode pertama belum memberikan dampak terhadap output sektor industri. Pengaruh guncangan investasi PMA mulai memberikan dampak pada periode kedua dan direspon positif oleh output sektor industri pengolahan sebesar 0.33 persen. Guncangan pada variabel investasi PMA direspon tajam pada periode kelima sebesar 2.26 persen. Setelah itu grafik menunjukkan penurunan pengaruh guncangan secara perlahan meuju titik keseimbangannya (convergance) pada periode kesepuluh sebesar 0.31 persen. Hal tersebut menunjukkan bahwa guncangan variabel investasi PMA memberikan pengaruh sementara terhadap variabel output sektor industri pengolahan. Guncangan yang diberikan juga tidak langsung memberikan dampak terhadap output sektor industri pengolahan selama satu periode, artinya membutuhkan waktu (lag) untuk dapat bisa dirasakan manfaatnya.

Guncangan yang terjadi pada variabel investasi PMDN sebesar satu standar deviasi, belum direspon pada periode pertama oleh variabel utama. Pada periode kedua guncangan tersebut direspon negatif oleh variabel PDRB sektor industri pengolahan sampai pada periode keempat. Guncangan tersebut mulai direspon positif pada periode kelima sebesar 0.26 persen dan kembali direspon negative oleh output sektor industri pengolahan pada periode keenam dan grafik impulse response menunjukkan pergerakan yang semakin mendekati titik keseimbangannya (convergance) pada periode kedelapan sebesar -0.17 persen. Hal tersebut juga menunjukan bahwa guncangan PDRB sektor industri pegolahan akan dirasakan manfaatnya setelah beberapa periode waktu (lag) dan mempelihatkan pengaruh yang sementara terhadap output sektor industri pengolahan.

Guncangan upah minimum provinsi (UMP) direspon berfluktuatif oleh output sektor industri pengolahan. Guncangan UMP belum direspon oleh output sektor industri pengolahan pada periode pertama. Guncangan tersebut direspon negative pada periode kedua sebesar 0.32 persen sampai pada periode keempat. Guncangan tersebut direspon positif pada periode kelima sebesar 0.38 persen dan kembali direspon negative pada periode keenam sebesar 0.45 persen. Setelah itu grafik impulse response mulai 
menunjukkan pergerakan yang semakin mendekati titik keseimbangannya sebelumnya pada periode kesembilan sebesar -0.16 persen. Hal tersebut menunjukkan guncangan variabel UMP tidak langsung direspon oleh output sektor industri yang mengindukasikan membutuhkan waktu (lag) untuk dirasakan manfaatnya dan guncangan pada variabel UMP memberikan pengaruh sementara terhadap output sektor industri pengolahan.


Sumber: Diolah, 2020

\section{Gambar 1. Hasil Uji IRF}

Guncangan variabel inflasi direspon berfluktuatif oleh output sektor industri pengolahan. Pada periode pertama guncangan tersebut belum memberikan respon terhadap output sektor industri pengolahan. Guncangan tersebut direspon positif pada periode kedua sebesar 1.14 persen. Setelah itu direspon negative pada periode ketiga sebesar 0.08 persen sampai periode keenam. Grafik impulse response menunjukkan pergerakkan yang semakin mendekati titik keseimbangan (convergence) atau kembali pada keseimbangan sebelumnya dan kembali direspon positif pada periode ketujuh sebesa 0.14 persen sampai pada periode kesepuluh. Hal tersebut menunjukkan bahwa guncangan variabel inflasi bersifat tidak permanen terhadap output sektor industri pengolahan.

Analisis FEVD melihat bagaimana kekuatan dan kelemahan dari masing-masing variabel dalam mempengaruhi variabel lainnya dalam jangka panjang (Firdaus 2011). Dengan kata lain FEVD memberikan informasi mengenai proporsi dari pergerakan secara berurutan yang diakibatkan dari guncangan dirinya sendiri dan variabel lainnya. Dalam penelitian ini waktu yang digunakan selama sepuluh periode (tahun). Gambar 3 menunjukkan bahwa pada periode pertama variabilitas PDRB sektor industri pengolahan secara berurutan didominasi oleh variabel dirinya sendiri, variabel impor dan ekspor. 
Kemudian terjadi perubahan kontribusi dalam jangka panjang, yaitu pada periode ke-10 dimana secara berurutan variabilitas industri pengolahan Jawa Tengah didominasi oleh variabel ekspor, pertumbuhan PDRB sektor industri, investasi PMA, impor, tenaga kerja, inflasi, variabel UMP dan investasi PMDN.

Dapat dilihat bahwa pada periode pertama, fluktuasi output PDRB sektor industri pengolahan secara dominan dipengaruhi oleh variabel dirinya sendiri dibandingkan dengan variabel lain yang ada dalam model sebesar 75.83 persen, disusul dengan variabel impor sebesar 19.80 persen, variabel ekspor sebesar 4.35 persen. Sementara itu pada periode yang sama variabel investasi PMA, PMDN, inflasi, tenaga kerja serta variabel UMP belum terlihat peranannya.

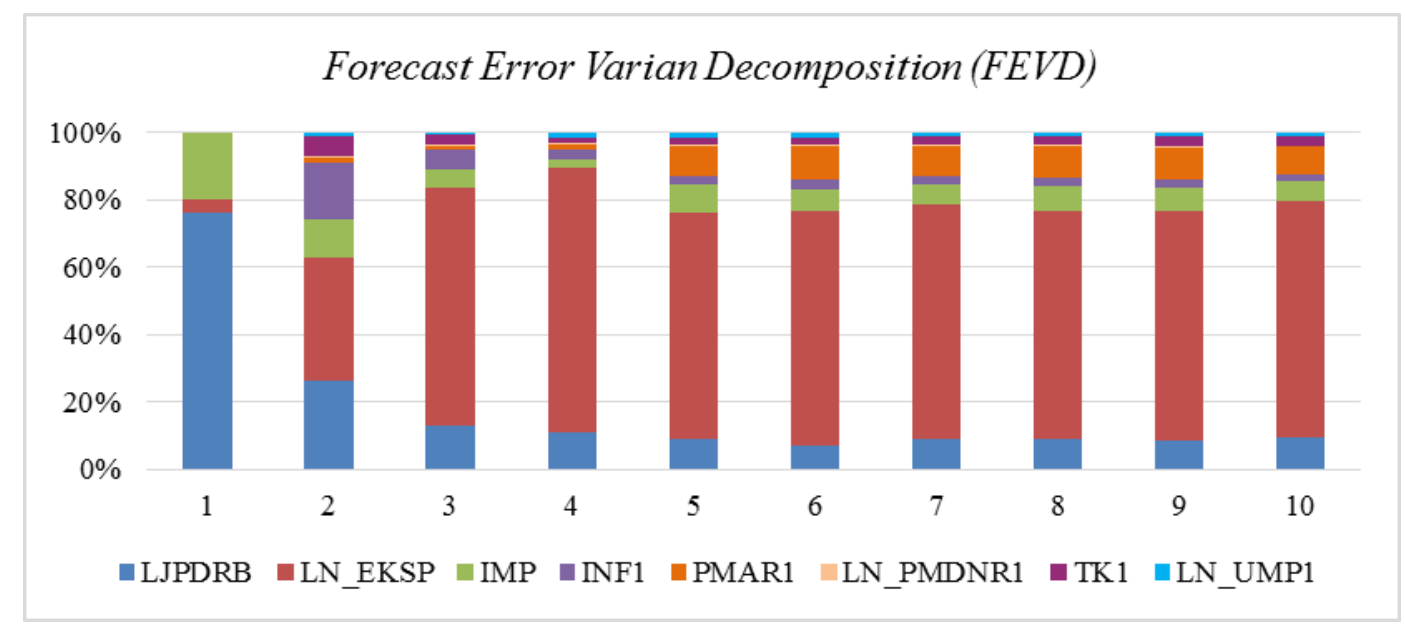

adaptation from Saefullah, 1993: 9, with modification

\section{Gambar 2. Hasil Uji Forecast Error Variance Decompisition (FEVD)}

Periode kedua mulai terjadi penurunan kontribusi variabel laju PDRB sektor industri dalam menjelaskan fluktuasi variabel dirinya sendiri menjadi 26.01 persen dan tampak variabel-variabel lainnya mulai mempengaruhi variabilitas laju PDRB sektor industri pengolahan, secara berturut-turut yaitu variabel ekspor 36.73 persen, variabel inflasi sebesar 17.03 persen, variabel impor 11.21 persen, jumlah tenaga kerja sebesar 5.77 persen, variabel investasi PMA sebesar 1.47 persen, variabel UMP sebesar 1.38 persen, investasi PMDN sebesar 0.37 persen. Pada periode ini menunjukkan penurunan dominasi pengaruh variabel laju PDRB sektor industri pengolahan dalam menjelaskan fluktuasi dari veriabel PDRB sektor industri pengolahan itu sendiri. Peranan variabel ekspor dalam menjelaskan variabilitas PDRB sektor industri pengolahan mulai mendominasi dan menunjukan peningkatan kontribusi yang signifikan dibandingkan variabel lainnya. Tampak pula peranan variabel lainnya mulai berpengaruh dalam menjelaskan variabilitas laju PDRB sektor industri pengolahan pada periode ini.

Pada periode lima tahun mendatang terjadi perubahan yang signifikan pada variabel-variabel dalam menjelaskan variabilitas laju pertumbuhan PDRB sektor industri. Dalam periode ini terlihat bahwa variabel PDRB mengalami penurunan kontribusi dalam menjelaskan fluktuasi laju PDRB industri itu sendiri serta bukan lagi menjadi variabel dominan dalam menjelaskan variabilitas laju PDRB sektor industri pengolahan yaitu sebesar 8.82 persen. Variabel ekspor mendominasi dan memiliki peran terbesar dalam menjelaskan fluktuasi output sektor industri pengolahan sebesar 67.12 persen. Terlihat 
bahwa terjadi peningkatan peranan variabel investasi PMA dalam memengaruhi variabilitas laju PDRB industri sebesar 8.94 persen, disusul dengan variabel impor sebesar 8.27 persen. Variabel inflasi sebesar 2.83 persen. Variabel tenaga kerja sebesar 1.89 persen. Variabel UMP dan investasi PMDN secara berturut-turut memberikan pengaruh terhadap variabilitas laju PDRB sektor industri sebesar 1.65 persen, 0.46 persen. Variabel investasi PMDN menunjukan pengaruh yang tidak terlalu besar namun mengalami peningkatan kontribusi dari lima periode sebelumnya.

Proyeksi periode kesepuluh menunjukan bahwa variabel ekspor menunujukan kontribusi yang dominan memengaruhi variabilitas laju PDRB industri pengolahan sebesar 70.03 persen dibarengi dengan peningkatan kontribusi dimulai pada periode keenam. Disusul dengan variabel laju PDRB sektor industri yang terus menunjukan penurunan kontribusi terhadap fluktuasi PDRB sektor industri setiap periodenya dengan variabilitas laju PDRB sektor industri sebesar 9.27 persen. Variabel investasi PMA menunjukan kontribusi yang terus meningktat setiap periodenya memengaruhi variabilitas PDRB sektor industri sebesar 8.28 persen. Variabel impor menunjukan kontribusi terus meningkat dalam memengaruhi variabilitas PDRB sektor industri pengolahan sebesar 6.09 persen. Variabel tenaga kerja menunjukkan kenaikan kontribusi setiap periode dalam memengaruhi variabilitas PDRB sektor industri sampai periode kesepuluh sebesar 2.74 persen. Variabel inflasi memberikan kontribusi terhadap fluktuasi PDRB sektor industri sebesar 1.93 persen dan mengalami penurunan kontribusi dari periode sebelumnya. Variabel UMP memberikan kontribusi yang kecil dalam menjelaskan variabilitas PDRB sektor industri pengolahan sebesar 1.30 persen dan investasi PMDN sebesar 0.37 persen. Hasil anaisis tersebut memperlihatkan bahwa faktor-faktor tersebut berperan dalam meningkatkan laju PDRB sektor industri di masa mendatang.

Sektor industri pengolahan merupakan leading sector yang memiliki peranan penting dalam meningkatkan perekonomian Provinsi Jawa Tengah. Peningkatan perekonomian daerah dapat didorong oleh sektor industri terutama industri pengolahan yang berorientasi ekspor (Ridhwan et al. 2015). Hal tersebut sesuai dengan penelitian ini yang menunjukkan bahwa kegiatan eskpor industri pengolahan mampu meningkatkan kinerja output sektor industri pengolahan Jawa Tengah. Daerah membutuhkan basis ekspor untuk menghasilkan barang yang dapat diperdagangkan ke daerah atau negara lain untuk mendorong pertumbuhan lokal (Iammarino and McCan 2013), karena sebagian besar sektor jasa merupakan sektor bersifat tidak diperdagangkan (non-tradable). Pembangunan industri Jawa Tengah harus didorong dan diarahkan pada industri berorientasi ekspor yang memiliki nilai tambah tinggi (value added) dan berdasarkan comparative advantage daerahnya baik berbasis SDA, padat karya, produk teknologi menengah ataupun teknologi tinggi. Selain itu, partisipasi industri pengolahan Jawa Tengah berbasis ekspor harus ditingkatkan di pasar internasional.

Salah satu kunci dalam meningkatkan kinerja sektor industri pengolahan Jawa Tengah adalah akumulasi modal melalui investasi, baik investasi dalam negeri (PMDN) ataupun investasi luar negeri (PMA) (Shenkar 2007; Iammarino 2013; McCann 2016). Penelitian ini juga menunjukkan pengaruh penting investasi, baik PMA dan PMDN dalam menigkatkan kinerja sektor indusri pengolahan Jawa Tengah. Investasi dalam negeri dan investasi luar negeri terkait peningkatan struktur industri harus lebih diarahkan untuk mendorong produktivitas dan penyerapan tenaga kerja yang lebih terampil (hight skill) serta mendorong industri-industri dalam proses ekspor (terkait teknologi dan inovasi serta infrastruktur).

Aliran investasi asing dapat membantu meningkatkan teknologi dan membantu memanfaatkan akses pasar global, membangun kapabilitas terkait pengetahuan di bidang industri pengolahan sehingga meningkatkan kemampuan dalam meningkatkan sistem produksi regional (McCan 2016). Investasi asing memungkinkan proses transfer teknologi yang berdampak pada penguatan struktur industri melalui proses belajar sehingga terjadi 
akumulasi pengetahuan. Pemerintah daerah harus menyediakan iklim lingkungan berusaha yang baik didaerahnya dalam mendorong investasi tersebut, menciptakan pemerintahan yang kooperatif dalam proses berusaha serta memberikan jaminan hukum yang jelas kepada para investor (asing dan domestik) yang akan menanamkan modalnya di Provinsi Jawa Tengah.

Otonomi daerah membuat inovasi kebijakan lebih ter design dan lebih mudah diterapkan oleh sektor publik. Melihat bagaimana struktur kinerja sektor industri pengolahan dibentuk dari berbagai faktor yang memengaruhinya, menggambarkan bahwa peningkatan sektor industri pengolahan dan pembuatan berbagai inovasi tidak dapat hanya diserahkan pada sektor private saja tetapi juga membutuhkan kolaborasi antara private sektor dan public sektor serta masyarakata luas, selain itu koordinasi lintas sektor (linkage) daerah-pusat diperlukan agar proses pembangunan berjalan sesuai yang diharapkan (McCann 2016).

Pemerintah daerah harus mampu meningkatkan peranannya dalam melakukan intervensi dan menciptakan berbagai inovasi kebijakan untuk mendorong kinerja indsutri pengolahan sesuai dengan karakteristik daerah dan keadaan geografisnya. Hal tersebut juga dapat menciptakan inovasi-inovasi kebijakan tidak hanya menempatkan industri sebagai sektor yang bertumpu pada produktivitas semata, tetapi manfaat spillover dan keterkaitan (linkage) serta kelembagaan yang menguntungkan dan dapat dirasakan manfaatnya oleh lokal dan regional (McCann 2016).

\section{KESIMPULAN}

Penelitian ini menunjukkan kenaikan output sektor industri pengolahan Jawa Tengah dalam jangka panjang dan jangka pendek. Jangka panjang dipengaruhi oleh variabel investasi PMDN dan investasi PMA, sementara jangka pendek dipengaruhi oleh variabel ekspor, dummy otonomi daerah, investasi PMA dan tenaga kerja. Hasil penelitian ini juga ditemukan bahwa faktor investasi PMA dan tenaga kerja dapat menurunkan output sektor industri pengolahan secara signifikan.

Hasil ini menekankan peran penting dari kegiatan ekspor dan investasi dalam meningkatkan konerja sektor industri pengolahan serta peran pemerintah dalam menciptakan inovasi kebijakan yang dapat mendorong terciptanya pembangunan sektor industri- industri di Jawa Tengah. Penelitian ini juga menunjukkan bahwa tenaga kerja sektor industri Jawa Tengah masih belum mampu menciptakan efisiensi bagi sektor industri yang sebelumnya diharapkan memiliki kompetensi dan keterampilan sehingga mampu menciptakan efisiensi kinerja industri pengolahan Jawa Tengah.

Hasil simulasi uji IRF dan FEVD menunjukkan bahwa secara berurutan variabel ekspor, variabel pertumbuhan output sektor industri, investasi PMA, impor dan tenaga kerja berperan dalam menjelaskan kinerja output sektor industri pengolahan di Jawa Tengah. Dengan kata lain variabel-variabel tersebut memiliki peran penting dalam mendorong kinerja output sektor industri pengolahan di Jawa Tengah di masa depan. Dengan demikian, Pemerintah perlu memperhatikan faktor- faktor tersebut guna mendukung kinerja sektor industri pengolahan Jawa Tengah.

\section{DAFTAR PUSTAKA}

Aftab RM, Ilyas M, Nawaz A, Safdar M. 2016. Trade Liberalization, Human Capital and Industrial Performance in Pakistan. Journal Sosial Science of Pakistan. 36(1): 563-572.

Alam NJ, Abbasi G dan Baseri B. 2014. Relationship between Exports and Economic Growth in the Industrial Sector in Iran. Journal of Business and Management Review. 3(8): 105-117.

Andrei MD, Andrei CL. 2015. Vector Error Correction Model in Explaining the Association of Some Macroeconomic Variabels in Romania. Journal Economics and Finance. (22): 568-576. 
Anwar S. 2008. Foreign Investment, Human Capital and Manufacturing Sector Growth in Singapore. Journal of Policy Modeling. 30(2008): 447-453. doi:10.1016/j.jpolmod.2007.12.008.

Aswicahyono H dan Rafitrandi D. 2018. A Review of Indonesia's Economic Competitiveness. Working Paper. WPSECO-01/2018. Centre of Strategic and International Studies.

Badriah SL, Alisjahbana SA, Wibowo K, Hadiyanto F. 2019. Labour Productivity Growth in the Industrial Sector of Indonesia: Structural Bonus or Structural Burden. Journal of Economic Studies Malaysian. 56(1): 139-159. doi.org/10.22452/MJES.vol56no1.7.

[Bapennas] Badan Pembangunan Nasional. 2010. Perubahan Produktivitas Industri Manufaktur Indonesia dan Faktor-Faktor yang Memengaruhinya Analisis Panel Data 2000-2007. Jakarta (ID): Laporan Akhir Bapennas.

[BKPM] Badan Koordinasi Penanaman Modal. 2018. Realisasi Investasi PMA dan PMDN Jawa Tengah. Jakarta (ID): Badan Koordinasi Penanaman Modal

[BPS] Badan Pusat Statistik. 2019. Provinsi Jawa Tengah Dalam Angka 2018. Semarang (ID): Badan Pusat Statistik Jawa Tengah.

Eng DVP. 2009. Total Factor Productivity and Economic Growth in Indonesia. Working Papper Trade and Development. The Australian National University.

Feng Ling, Zhiyuan Li and Deborah S. The Connection between Imported Intermediate Inputs and Exports: Evidance from Chinese Firms. \ournal of International Economics. 101 (2016): 86-101. doi: 10.1016/j.jinteco.2016.03.004.

Firdaus M. 2011. Aplikasi Ekonometrika Untuk Data Panel dan Time Series. Bogor (ID): PT Penerbit IPB Press

Hapsari DR. 2016. Penanaman Modal dan Pertumbuhan Ekonomi Tingkat Provinsi di Indonesia. Jurnal Ekonomi dan Bisnis. 19(2): 211-224.

Iammarino S, McCann P. 2013. Multinationals and Economic Geography: Location, technology and Innovation. United Kingdom (UK): Edward Elgar Publishing Ltd.mbruno

Imbruno M, Ketterer. 2018. Energy Efficiency Gains from Importing Intermediate Inputs: Firm-level Evidence from Indonesia. Journal Economic Development. 135(2018): 117-141.

Jhingan LM. 2008. Ekonomi Pembangunan Dan Perencanaan. Jakarta. PT Raja Grafindo Persada.

Juanda B, Junaidi. (2012). Ekonometrika Deret Waktu. Bogor: PT Penerbit IPB Press.

Kilavuz E, Topcu AB. 2012. Export and Economic Growth in The Case of the Manufacturing Industry: Panel Data Analysis of Developing Countries. Journal of Economics and Financial Issues. 2(2): 201-215.

Kustanto H. 2012. Deindustrialisasi dan Dampak Reindustrialisasi Terhadap Ekonomi Makro serta Kinerja Sektor Industri Non-Migas di Indonesia [disertasi]. Bogor (ID): Institut Pertanian Bogor.

Latip D. 2009. Analisis Pengaruh Penanaman Modal Asing Langsung (FDI) terhadap Pertumbuhan Ekonomi Regional Propinsi Tahun 2000-2006 [tesis]. Salemba (ID): Universitas Indonesia

McCann P. 2016.The UK Regional- National Economic Problem: Grography, Globalization and Governance. New York (Eng): Routledge.

Novitasari DY 2015. Dampak Keterbukaan Perdagangan dan Kinerja Manufaktur di Indonesia. Jurnal Ekonomi dan Kebijakan Pembangunan. 4(2): 172-186.

Ostry, Jonathan D, Atish RG, Karl H, Marcos C, Mavhash SQ, Dennis R. 2010. Capital inflows: The Role of Controls. International Monatary Fund, 2010

Palupy EH, Basuki UM. 2019. Analisis Pengaruh Investasi dan Budget Defisit Terhadap Pertumbuhan di Indonesia. Jurnal Ekonomi. 1(1): 67-79.

[PEMPROV JATENG] Pemerintah Provinsi Jawa Tengah. 2019. Kejar 7\% pertumbuhan ekonomi Jateng genjot investasi [internet]. diakses Desember 2019. https://jatengprov.go.id/publik/kejar-7-pertumbuhanekonomi-jateng-genjot-investasi/.

Prasetyo BR, Firdaus M. 2009. Pengaruh Infrastruktur pada Pertumbuhan Ekonomi Wilayah di Indonesia. Jurnal Ekonomi Kebijakan Pembangunan. 2(2): 222-236.

Pratiwi K, Nurbani IR, Pakpahan MY. 2005. Analisis IRIO dalam Pembangunan Industri Pada Era Otonomi Daerah. Jurnal Ekonomi dan Pembangunan. 5(2). 57-73 doi.org/10.21002/jepi.v5i2.123

Ridhwan MM, Wicaksono G, Nurliana L, Bary P, Suryani TF, Satyanugroho R. 2015. Analysis of Competitiveness and National Strategic Industries in the Era of The ASEAN Economic Community and Free Trade. Working paper. No. LH/3/2015, Bank Indonesia.

Rukumnuaykit P, Pholphirul P. 2015. Human Capital Lincages to Labour Productivity: Implications from Thai Manufactures. Journal of Education and Work. ISSN: 1363-9080 (Print) 1469-9435. doi:10.1080/13639080.2015.1104658.

Rustiadi et al. 2011. Teknik Analisis Perencanaan Pengembangan Wilayah. Jakarta: Yayasan Obor Indonesia. 
Shenkar 0. 2007. The Chinese Century. Gramedia: Jakarta.

Sitorus AM. 2008. Hubungan antara Nilai Tukar Pertumbuhan Ekonomi dan Investasi Langsung dengan Ekspor Non Migas Indonesia ke Jepang. Suatu Adaptasi Model Goldberg-Klein dan Analisis Regresi. [skripsi]: Jakarta (ID): Universitas Indonesia.

Szkorupova Z. 2014. A Causal Relationship between Foreign Direct Investment, Export and Economic Growth for Slovakia. Procedia Economic and Finance. 15(14). 123-128. Doi: 10.1016/S2212-567100458-4

Todaro PM dan Smith S. 2006. Pembangunan Ekonomi. Ed- 9. Erlangga dan Power Machintosh

[UNIDO] United Nation Industrial Development Organization. 2019. World Manufacturing 